Peter Goddard

is the Dubai-based Middle East managing director of TRI Hospitality Consulting. Peter has more than 15 years of experience in the hospitality, tourism and real estate industries, including hotel managerial positions in Australia and Switzerland.

Guy Standish-Wilkinson, managing consultant at TRI Hospitality Consulting, is a senior hospitality consultant who has managed and contributed to more than 120 hotel market and feasibility studies, as well as property surveys, operational reviews and valuations throughout the wider Middle East region.

Keywords:

hotels, management contracts, clauses, owners, operators, Middle East, base fee, incentive fee
Peter Goddard and Guy StandishWilkinson

TRI Hospitality Consulting

PO Box 31933

Dubai, UAE.

Tel: +971 43454241

Fax: +971 43458502

E-mail: trihc@emirates.net.ae

\section{Hotel management contract trends in the Middle East}

\author{
Peter Goddard and Guy Standish-Wilkinson \\ Received (in revised form): 13 September 2001
}

\begin{abstract}
When the international hotel chains first established a significant presence in the Middle East in the 1970s and 1980s, it was a developing region, their skills were at a premium, and they could effectively name their own management contract terms. As markets matured in the 1990s, owners took more control over their properties in a bid to increase operating profits, and competition increased among a larger pool of operators. Facing an increasing emphasis on incentive fees, shorter contract periods, fewer renewal options and demanding performance clauses, the chains are now working harder to make less money, and are left only two options: take on more contracts, or invest equity in a bid for better fees.
\end{abstract}

\section{INTRODUCTION}

The Middle East as defined by most international hotel management chains may be said to comprise the Gulf Cooperation Council states (Saudi Arabia, Kuwait, Bahrain, Qatar, the United Arab Emirates and Oman), Yemen, the Levant (Syria, Jordan, Lebanon and Palestine) and Egypt. Operators typically keep Israel as part of a separate administrative region to avoid political difficulties. African Arabic-speaking countries like Sudan and those of the Maghreb (Libya, Algeria, Tunisia and Morocco) may also be linked to the above countries, as well as the rest of Africa, and West Asia/the subcontinent of India, Pakistan, Bangladesh and Sri Lanka.

In economic terms, this vast region has traditionally been viewed as either developing or underdeveloped. Nevertheless, when the major international hotel chains first ventured into international markets in the 1950s and 1960s, the capital cities of the Middle East were attractive management contract targets, precisely because of the local markets' lack of expertise.

The first international chain hotel in the Middle East was the Nile Hilton, opened in Cairo in 1959 and still going strong. The Gulf's first luxury hotels appeared in the late 1970s and during the 1980s a reliable infrastructure of luxury properties was established in all its major cities.

Chains like Hilton, InterContinental, Sheraton, Hyatt, Marriott and Forte typically operated the top tier of hotels, while at the next level down (some nominally five-star but actually four-star hotels) there was Holiday Inn, Ramada, Novotel, Le Meridien and a host of independents. 


\section{Management contract territory}

\section{Owners gaining strength}

Until now, management contracts have been the preferred business structure for the international operators, for several reasons. Most importantly, operators can make attractive profits without capital outlay, and at the same time minimise perceived risk in this often unstable part of the world. Equally, foreign direct land and property ownership is typically not allowed in many Middle Eastern countries, and where foreign business participation is sanctioned, it is usually to a maximum of 49 per cent. Notably, even in those countries that are now making foreign property ownership laws more flexible, such as Bahrain, the chains have not leapt in to buy.

Traditionally, hotel management companies were in a very strong negotiating position when it came to deciding the terms of operator agreements to manage hotels on behalf of owners. The operator held most of the negotiation cards. It had skilled and experienced negotiation teams; established policies, procedures and management expertise that were vital to the success of the new operations; a name and reputation demanded by lenders and investors; and a marketing and referral network vital for the competitive edge in the growing international tourist and commercial market.

Owners, on the other hand, tended to be somewhat unsophisticated in relation to hotel operations. They seemed to believe that the level of control and power that was afforded to the operator was unassailable; termination provisions were weak, performance criteria non-existent; terms were long and fees and costs in dollar terms increased substantially during periods of unexpected inflation.

However, in recent years the bargaining position has shifted. Owners are more sophisticated and have access to experienced negotiators and lawyers; there are more international-standard operators competing for fewer property management opportunities; and hotel developers, owners and lenders alike realise that the quality of the agreement has a direct bearing on the saleability and value of the hotel. They also understand the hotel business more than previously.

Many Middle Eastern hotel owners are also increasingly looking to the now more mature local hotel sector and labour markets to supply the requisite management expertise to run their properties. A new generation of aggressive management or owner/operator chains like Rotana (UAE), Metropolitan (UAE) and Safir International (Kuwait) counters the international chains with unique selling points including authentic cultural sensitivity, lower superstructure and therefore overheads, nimbler decision making, and even first-hand experience as owners themselves.

This paper profiles the major trends in hotel management contracts, focusing on a range of management contracts in the Middle East region. 


\section{MIDDLE EAST SURVEY}

TRI Hospitality Consulting conducted a survey of 12 current or recently terminated hotel management contracts in the Middle East and West Asia. All contracts were for upmarket properties. Due to the sensitive nature of hotel management contracts, the authors are not at liberty to reveal the names of the management companies.

Of this group, nine four- and five-star agreements were chosen as the most recent examples of management agreements. A summary of these agreements and their major commercial terms is presented in Table 1.

\section{MAJOR NEGOTIATION POINTS}

There are approximately 100 major negotiation points that need to be addressed in any management contract negotiation. The outcome of the negotiation of these 100 items will have an immediate and lasting effect on the value of the property, the cash flow likely to accrue to the owner and the performance and manageability of the operator.

In this survey, the majority of the commercial aspects and a number of the key legal clauses were examined. These are summarised in Table 2 and discussed below.

\section{THE NATURE OF THE CONTRACTUAL ARRANGEMENT}

The nature of the contractual arrangement is in effect an agency situation where the operator acts solely on behalf of the owner. The operator handles all receivables and liabilities in the performance of its duties and is paid for the management of the property. Despite wording to the effect that this does not constitute an agency or a joint venture or partnership, the description as defined in management agreements does in effect constitute an agency in US case law.

Marriott recently lost a very important court case in California that proved that the hotel operator is indeed the agent of the owner. This is an important point because all owners view the operator as their agent, despite wording to the contrary in management agreements upheld in US federal courts.

This is further reinforced by the operator's exclusive right to manage and have 'quiet enjoyment' of the property. Owners increasingly refuse to indemnify the operator for its omissions due to neglect or otherwise relating to its management of the property, and yet many hotel groups still have this type of clause in their agreements (for example, Sheraton/Hilton).

\section{PRE-OPENING SERVICES}

Pre-opening management services cover staff hiring and training, marketing, operating equipment, commissioning inventory procurement, system installation and negotiation of service contracts and tenant leases on behalf of the owner.

Compensation for pre-opening services can be structured in a 
Table I: Hotel management contracts surveyed

\begin{tabular}{|c|c|c|c|}
\hline Property & I & 2 & 3 \\
\hline Country & Saudi Arabia & Egypt & United Arab Emirates \\
\hline Number of rooms & Over 400 & Over 300 & Between 150 and 225 \\
\hline Quality & Five-star & Five-star & Four-star \\
\hline Agreement date & 1994 & 1994 & 1998 \\
\hline Term of contract & $\begin{array}{l}\text { Ten years from opening date, three } \\
\text { option periods of five years each, } \\
\text { mutually agreed by each party }\end{array}$ & $\begin{array}{l}\text { Fifteen years from opening date, two } \\
\text { option periods of ten years each, } \\
\text { mutually agreed by each party }\end{array}$ & $\begin{array}{l}\text { Twenty years from opening date, one } \\
\text { additional term of five years, unless either } \\
\text { party gives written notice six months prior } \\
\text { to expiration }\end{array}$ \\
\hline Base management fee & No & $1.5 \%$ of gross revenue & $2 \%$ of gross revenue \\
\hline $\begin{array}{l}\text { Incentive management } \\
\text { fee }\end{array}$ & $\begin{array}{l}17.5 \% \text { of net profit, operator to receive } \\
\text { a minimum of US } \$ 180,000 \text { per annum }\end{array}$ & $10 \%$ of gross operating profit & $10 \%$ of gross operating profit \\
\hline Equity contribution & No & No & No \\
\hline Marketing contribution & No & At cost & $2 \%$ of gross rooms revenue \\
\hline Pre-opening expenses & At cost & At cost & At cost, approval of budget required \\
\hline Technical assistance fees & US $\$ 150,000$ in five equal instalments & US\$1,750 per room & $\begin{array}{l}\text { Technical services US } \$ 750 \text { per room; } \\
\text { commitment fee US } \$ 400 \text { per room }\end{array}$ \\
\hline Performance clause & $\begin{array}{l}\text { Owner must receive minimum of } \\
\text { SR36m (US\$10m) in year } 1 \text { escalating } \\
\text { to SR52m }(\$ 14 \mathrm{~m}) \text { in year } 10\end{array}$ & No & $\begin{array}{l}\text { Yes, linked to interest and principle } \\
\text { repayment over five years }\end{array}$ \\
\hline Non-compete clause & Yes & Yes & No \\
\hline $\begin{array}{l}\text { Furniture, fixtures and } \\
\text { equipment reserve }\end{array}$ & $\begin{array}{l}4 \% \text { of gross revenue from year } 1 \text { to } \\
\text { year } 10\end{array}$ & $\begin{array}{l}\text { Year } 1,1 \% \text {; year } 2,2 \% \text {; year } 3 \text { and } \\
\text { thereafter, } 3 \% \text { of gross revenue }\end{array}$ & $4 \%$ of adjusted gross revenue from year 1 \\
\hline Sale of hotel & Consent required from operator on & Consent required from operator & Consent required from operator \\
\hline
\end{tabular}

Property 4

Country

Number of rooms

Quality

Agreement date

Term of contract

Base management fee Incentive management fee Equity contribution

Marketing contribution

Pre-opening expenses

Technical assistance fees

Performance clause

Non-compete clause

Furniture, fixtures and

equipment reserve

Sale of hotel

\section{Property}

Country

Number of rooms

Quality

Agreement date

Term of contract

Base management fee Incentive management fee Equity contribution Marketing contribution Pre-opening expenses Technical assistance fees

Performance clause

Non-compete clause

Furniture, fixtures and equipment reserve

Sale of hotel

\section{7}

sale of property, otherwise operator will receive US\$180,000

United Arab Emirates

Over 250

Five-star

1996

Fifteen years from opening date, one option period of five years, mutually agreed by each party

$2 \%$ of total revenue

$10 \%$ of gross operating profit No

$1.5 \%$ of gross rooms revenue At cost

US\$1,000 per room

No

Yes

Year 1, 1\%; year 2, 2\%; year 3 and thereafter, $3 \%$ of adjusted gross revenue Mutual consent of both parties

Lebanon

Between 200 and 250

Four- to five-star

1994

Ten years from opening date, two option periods of five years each, mutually agreed by each party

$1.5 \%$ of total revenue

$8 \%$ of gross operating profit No

$2 \%$ of gross rooms revenue

At cost

US\$1,000 per room

No

Yes

Year 1, 1\%; year 2, 2\%; year 3 and thereafter, $3 \%$ of total revenue Mutual consent of both parties
United Arab Emirates

Between 275 and 325

Four-star

1998

Ten years from opening date, two option periods of five years each, mutually agreed by each party

$2 \%$ of gross revenue

$8 \%$ of gross operating profit No

US\$5 per reservation

At cost

US\$750 per room

Linked to interest and principle

Yes

Year 1, 1\%; year 2, 2\%; year 3 and

thereafter, $3 \%$ of gross revenue

Owner's right to sell without operator's Mutual consent approval

\section{8}

United Arab Emirates

Between 250 and 300

Four- to five-star

1996

Ten years from opening date, two option periods of five years each, mutually agreed by each party

No

$14 \%$ of adjusted gross operating profit

No

$1 \%$ of room revenue

At cost

N/A

Linked to gross operating profit Yes, if same concept

Year 1, 1\%; year 2, 2\%; year 3 and thereafter, $3 \%$ of total revenue

Owner's right to sell without operator's approval
Saudi Arabia

Between 200 and 300

Five-star

1998

Fifteen years from opening date, one additional term of ten years

$1 \%$ of total revenue $8 \%$ of gross operating profit Yes

US\$5 per reservation

At cost

US\$1,000 per room

Linked to GOP

Yes

$3 \%$ of gross revenue

9

India

Between 300 and 400

Five-star

1990

Fifteen years from opening date, two additional terms of ten years

$3 \%$ of total revenue

$10 \%$ of gross operating profit

No

US\$5 per reservation

At cost

$1.5 \%$ of construction cost excluding land, interest and principle repayments

No

Yes

Year 1, 1\%; year 2, 2\%; year 3 and thereafter, $3 \%$ of total revenue

Negotiated between owner and operator on sale of property 
Table 2: Management contract provisions - Middle East region

\begin{tabular}{|c|c|c|c|}
\hline & Definition & $1980 \mathrm{~s}$ & Present \\
\hline Management fees & $\begin{array}{l}\text { The remuneration the owner agrees to } \\
\text { pay the operator for performing the } \\
\text { duties specified in the contract }\end{array}$ & $\begin{array}{l}\text { Base: } 2.5-3.5 \% \text { of gross revenue } \\
\text { Incentive: } 8-14 \% \text { of income before } \\
\text { fixed charges }\end{array}$ & $\begin{array}{l}\text { Base: } 1-2 \% \text { of gross revenue } \\
\text { Incentive: } 6-12 \% \text { of adjusted income } \\
\text { before debt service }\end{array}$ \\
\hline Contract term & $\begin{array}{l}\text { Length of time that the agreement is to } \\
\text { remain in effect. Includes the initial term } \\
\text { and more renewal terms that extend } \\
\text { the total length of the agreement }\end{array}$ & $\begin{array}{l}\text { Fifteen to } 20 \text { years initial term with } \\
\text { one to three renewal options for five } \\
\text { to ten years }\end{array}$ & $\begin{array}{l}\text { Eight to } 12 \text { years initial term with one } \\
\text { renewal term of five to ten years }\end{array}$ \\
\hline Performance clause & $\begin{array}{l}\text { Sets specific operating performance that } \\
\text { the operator must meet in order to } \\
\text { receive management fees. Typically } \\
\text { linked to gross operating profit, also } \\
\text { known as a 'stand-aside provision' }\end{array}$ & Not common & Common \\
\hline System reimbursable charges & $\begin{array}{l}\text { Payment to operator for advertising, } \\
\text { sales offices, reservation accounting, } \\
\text { purchasing systems and training } \\
\text { programmes }\end{array}$ & $\begin{array}{l}1-2 \% \text { of gross rooms revenue plus } \\
\text { US } \$ 5-10 \text { per reservation }\end{array}$ & $\begin{array}{l}1 \% \text { of gross rooms revenue plus } \\
\text { US\$4-8 per reservation }\end{array}$ \\
\hline Hotel personnel & $\begin{array}{l}\text { Relates to whether the personnel } \\
\text { employed in the hotel are employees } \\
\text { of the owner or of the management } \\
\text { company }\end{array}$ & $\begin{array}{l}\text { Operator has sole right to select, } \\
\text { appoint and supervise all hotel } \\
\text { employees }\end{array}$ & $\begin{array}{l}\text { Operator requires approval of owner } \\
\text { before hiring general manager and } \\
\text { financial controller }\end{array}$ \\
\hline Restrictive covenant & $\begin{array}{l}\text { A specific geographic area within which } \\
\text { further hotels cannot be developed }\end{array}$ & Not common & Common \\
\hline Reserve for replacement & $\begin{array}{l}\text { A fund set up to accumulate capital for } \\
\text { the periodic replacement of furniture, } \\
\text { fixtures and equipment }\end{array}$ & $3-5 \%$ of gross revenue & $\begin{array}{l}3-5 \% \text { of gross revenue. It is in the } \\
\text { owner's and the operator's best } \\
\text { interest to maintain the hotel } \\
\text { adequately }\end{array}$ \\
\hline $\begin{array}{l}\text { Operator's equity } \\
\text { contribution or debt } \\
\text { financing }\end{array}$ & Capital or finance provided by the operator & Not common & $\begin{array}{l}\text { Increasingly common with mid-market } \\
\text { properties but limited to the purchase } \\
\text { of furniture, fixtures and equipment }\end{array}$ \\
\hline Termination clause & $\begin{array}{l}\text { Either party may terminate due to } \\
\text { bankruptcy of the other party, material } \\
\text { breach, fraud or condemnation }\end{array}$ & Favours the operator & Favours the owner \\
\hline Owner approvals & $\begin{array}{l}\text { May include the approval of capital } \\
\text { expenditures, the annual budget and } \\
\text { marketing plan changes in restaurant } \\
\text { concepts and key personnel }\end{array}$ & Favours the operator & Favours the owner \\
\hline Transfer of ownership & $\begin{array}{l}\text { Usually involves certain criteria to be } \\
\text { met, but not to be unreasonably withheld }\end{array}$ & Favours the operator & Favours the owner \\
\hline Technical assistance fee & $\begin{array}{l}\text { Paid to operator for technical aspects } \\
\text { of hotel layout, design, construction and } \\
\text { furnishing }\end{array}$ & $\begin{array}{l}\text { US } \$ 1,000-1,500 \text { per room plus } \\
\text { expenses }\end{array}$ & $\begin{array}{l}\text { US\$1,000-1,500 per room plus } \\
\text { expenses }\end{array}$ \\
\hline Pre-opening expenses & $\begin{array}{l}\text { Paid to operator for developing the } \\
\text { pre-opening plan and budget, and for } \\
\text { supervising pre-opening activities } \\
\text { including training, marketing and } \\
\text { procuring all supplies }\end{array}$ & At cost & At cost \\
\hline
\end{tabular}

number of ways. It is difficult to define a typical pre-opening fee, because many operators are willing to provide these services at or near their cost in order to obtain a long-term management contract, so provisions for them are generally negotiated concurrently with the management contract. In a majority of the surveyed contracts, pre-opening expenses were billed at or near cost.

\section{TECHNICAL SERVICE ASSISTANCE}

Technical service assistance encompasses the technical aspects of a hotel layout, design, construction and furnishing. Compensation for technical service assistance is generally a negotiated flat fee paid in 
stages over the development phase. These services are usually considered separate to and distinct from the pre-opening services because they require a specialised level of expertise. In this survey on a per-available-room basis, the technical services fees tended to range from US\$500 per room, to US\$1,250 per room.

In recent years, owners in the USA have been attempting to include technical assistance fees, pre-opening budgets and performance provisions in management fees. If the operator wants a project, he must look to be as creative as possible in the fee structure to accommodate the specifics of the property and owner/ bank requirements.

\section{TERM}

An operator will argue for a longer term, based on the premise that the company's initial set-up costs and effort take up to five years to recoup, and a longer period will provide stability to the property and continuity in the market.

A lender may influence an owner to sign for a longer term so that the management period extends for as long as the financing agreements. This argument is based on a premise that an internationally recognised brand is an asset of the property and adds value to the property's worth and therefore the bank's security. The owner, on the other hand, often wants maximum flexibility, the benefit of corporate branding, plus a period that gives stability, but with an early option period to enable an escape if he so desires.

Operators today argue for a longer initial period with at least two options at their discretion. Operators often have their operating agreements formally valued/appraised and incorporated in their balance sheet as an asset. Because the value of agreements is enhanced by a longer term, there is a financial benefit in obtaining extended periods.

The market these days, however, is progressively favouring

\section{Shorter terms} shorter management contract periods. The reasoning is quite clear. If things go well - and typically there are hotel market cycles of approximately seven years - the owner is by and large quite happy to renew on the same terms. If things are difficult, or the relationship is a disaster, the owner will only renew if he has substantially improved terms.

\section{Option period/renewal term}

The trend which has seen a shortening in the length of the initial term of contracts flows through to the number and length of options. Early contracts included an initial 20-year contract and an average of two options periods, each of ten years' duration, always giving the operator the option of renewal. These contracts had few, if any, provisions for early termination, giving even more significance to the automatic renewal terms. Nowadays, the ten plus five-year option is more typically favoured by owners. 


\section{Fewer options}

Three plus ten to one plus eight
Where the owners surveyed had bargaining strength, they tended to negotiate a say in the option take-up, either by including some performance provisions before the option was triggered or by having the option only taken up on mutual agreement. As there is no compensation to the operator if an option is not granted, operators today would prefer to concede buy-out formulae on termination without cause or upon sale of the property and maintain their control of the option periods. In this way they are assured of a compensation payment if the contract period is terminated.

\section{MANAGEMENT FEES}

The owner pays fees to his manager for services rendered in three areas:

- pre-opening assistance and technical services (see above);

- day-to-day management of the hotel;

- operator head office assistance and system reimbursement.

Once the hotel is operational, a hotel company receives a management fee as compensation for providing the various services detailed in the management agreement.

Fees tend to be structured as either:

- a basic management fee;

- a basic management fee plus an incentive fee; or

- an incentive fee only.

The traditional structure, both in the Middle East and elsewhere, was the 'three plus ten' agreement, where three per cent of gross revenue was the basic management fee and ten per cent of gross operating profit (GOP) was the incentive fee. The norm is now one-two per cent of total revenue plus eight-ten per cent of adjusted gross operating profit (the surplus available after fixed costs and before debt service).

The incentive management fee is normally based on GOP, the level of profit on which the operator can have an influence. Operators argue that tying the performance to GOP is necessary because they cannot influence expenses incurred below the GOP level.

Those expenses, which are incurred by the owner, include:

— building insurance;

- rates and taxes;

- fixtures and fittings reserve;

- interest;

- depreciation;

- income taxes.

The incentive management fee rewards the management company for expenses control and profitable operations. 
Percentage fee

\section{'Stand-aside provisions'}

Adjustments to GOP make allowances for a number of the fixed costs detailed above, usually building insurance and rates and taxes.

\section{MARKETING CONTRIBUTION}

These are fees paid by the owner to the operator to cover services provided outside the hotel, usually on a chainwide basis. They include such things as corporate marketing support, central reservation services, centralised human resources support and training.

Initially these services were clearly stated, verifiable, and apportioned to all hotels within the system on a pro rata basis, usually based on room numbers. Today this tends to have been replaced by a percentage fee based on gross rooms revenue. This has made verification redundant for the operator, but over time can represent a considerable additional expense to the hotel.

Most operators make an additional charge for reservations taken by the chain's central reservation system on behalf of the hotel. This service fee is usually specified in the operating agreement, as is the manner of calculation. The fee varies between companies from between US\$5 to US\$15 per reservation. Many contracts nowadays have no fee for marketing contribution if there is a fee payable per reservation.

\section{OPERATOR PERFORMANCE}

Today it is common to find some form of operator performance provision in a management contract. As competition for fewer contracts increases, more contracts will include these provisions.

The most common performance provisions relate to a level of GOP that needs to be achieved before the manager is entitled to the agreed incentive fee. These clauses, usually referred to as 'standaside provisions', require the operator to stand aside from all or part of its incentive fees until the pre-agreed level of GOP is achieved. In some instances, the manager is also required to 'top up' the owner's return from both its base fee and incentive fee to the maximum level of their fees, if the minimum agreed return is not achieved. Performance criteria of this style are usually only in place for the initial five to ten years. However, in some instances, they cover the life of the contract.

True operator guarantees relate to a level of profit performance that is agreed by both parties. In these instances, the operator is required to 'make good' or 'cure' any shortfall in the guaranteed profit regardless of the level of fees earned. In many contracts, this shortfall can be paid by way of an interest-free loan from the owner. If the operator does not top up the shortfall from its own resources, it is in default under the agreement. Usually in these instances, and in those detailed above where fees are used to top up, the operator has the right to 'claw back' (in future years) forgone fees or money and loans contributed if and when the performance levels are exceeded. 
Operators usually argue successfully that if performance guarantees are to be put in place, then they should not be enforced if unfavourable economic or market conditions prevail outside an agreed level. Such events as wars, transport strikes, levels of inflation and economic downturns are often specified in this regard.

\section{FINANCIAL PERFORMANCE REQUIREMENTS}

Owners and their advisers are recognising the need for specific termination provisions based upon objective financial performance criteria. This is shown by the fact that most of the management contracts reviewed in this survey provided for set operator financial performance targets.

The most common form of such termination provisions in the sample group was a right for the owner to terminate where the actual GOP fell short of the budgeted GOP for an agreed number of consecutive years. Often, however, this was subject to events beyond the operator's control, with the provisos mentioned above.

TRI found that there tended to be two preferred performance criteria:

- actual GOP compared to budgeted GOP;

- a negotiated dollar target set down for each year of the agreed period, or a base figure that is increased annually by CPI (Consumer Price Index, or part thereof) for the life of the contract.

\section{TERMINATION}

The specific provisions for termination of a management contract are crucial, particularly in relation to termination without cause. Owners have found that it is often extremely difficult to terminate a management contract (where there are no specific non-performance provisions) upon the basis that the operator is performing inadequately. Accordingly, rather than risk difficult and expensive litigation, it is in the owner's interests to have provisions in the management contract which allow him to terminate where the operator has not satisfied objective performance criteria.

Furthermore, this sample demonstrates there is an increasing trend by owners to seek to have the ability to terminate management contracts as of right and without cause upon payment of an agreed fee (see below).

\section{Standard termination provisions}

There are a number of standard events of default which tend to be contained in most management contracts, irrespective of the term of the agreement or the relative bargaining strengths of the parties. These include such things as:

— the failure of a party to observe, keep or perform any material 


\section{No termination without justification}

covenant, agreement or provision of the management contract and continuation of such failure for a specified period after the defaulting party is given notice to cure the default;

- the insolvency of a party;

- the failure to maintain insurance;

- the failure by the owner to maintain adequate working capital or to pay the operator any money due to it.

There are other standard provisions, which allow the management contract to be terminated in certain circumstances, such as where the hotel is substantially damaged or destroyed; or where the hotel is condemned in whole or in part.

As referred to above, owners find it extremely difficult to terminate an agreement where the owner believes the operator is not performing adequately if there are no specific performance provisions. Hotel management contracts are often very nebulous as to the standard at which operators must perform. This is in part a function of the operator's desire not to be bound by tightly worded provisions, but also because of the difficulty in describing adequately the standard at which operators must perform.

Consequently, it is extremely difficult for an owner to attempt to terminate an agreement based upon the argument that the operator has breached a material provision of the agreement (being its agreement to manage the hotel with the skill and to the degree expected of an experienced hotel operator). To adduce evidence is not easy, and as this invariably involves a question of fact, any court proceedings tend to be lengthy and expensive. In the meantime, the ongoing operation of the hotel is put in jeopardy. If the owner terminates the agreement improperly and ultimately loses in any court case, then he can also be exposed to a very large damages claim.

It is for these reasons that the trend in recent management contracts is to provide that the owner can terminate if objective financial performance criteria are not attained.

A harsh reality of working in the Arabian Gulf that some international operators have had to face in recent years is that many owners are members of the extensive local royal or leading trading families. From breaking heads-of-agreement commitments to contract termination before time, influence in this region has been known to count more than any court ruling ever could.

\section{Termination without cause}

Termination without cause allows the owner to terminate the management contract without the need to give or justify any reason for so doing. Normally the owner must pay the operator a fee as compensation, either a set dollar amount or a formula based on the previous year's fees multiplied by an agreed multiplier, usually three to five times.

In a number of cases, the longer the remaining term of the 
All care, no responsibility management agreement, the larger the termination fee. Often these provisions are contained in side agreements.

\section{Termination on sale of the hotel}

All of the management contracts in the sample provided that any purchaser of the hotel had to be respectable, responsible and financially sound and had to assume the owner's obligations under the management contract. In most cases, the operator's actual approval was required. In three cases, the operator had a right of first or last refusal to purchase the hotel, a clause that very often can inhibit the saleability of the hotel.

A growing number of the management contracts today provide that the owner can terminate the management contract on the sale of the hotel, provided that a minimum period of notice is given and a termination fee is paid to compensate the operator for the loss of the balance of the contract. The provisions relating to this fee are similar to the termination fee where there is a termination without cause.

\section{CONTROL}

Older management contracts were primarily drafted on the basis that the operator would take all care but accept no responsibility, and would have absolute control in the management of the hotel. Indeed, it was not unusual to find a provision in a management contract that the owner would ensure the operator was given exclusive undisturbed possession and control of the property. While the operator at times would allow the owner to ask questions concerning matters such as budgets, human resources and marketing activities, the operator would not tolerate having to seek the owner's approval to any of these matters.

The common argument put forward by operators was that if they were given the job of managing the hotel and if a substantial part of their fee was based upon their performance, then they should have the right to manage the property unfettered by the owner. Increasing competition among operators and greater sophistication of owners has resulted in owners insisting upon greater control over areas such as budgets, spending and personnel.

\section{Budgets}

In some ways the determination of the annual budget and business plan is the single most important activity for an owner, as it is the framework from which a number of matters will be determined, such as:

- the gross operating profit for the year;

- the operator's exposure to stand asides;

- the estimated incentive fees which will be payable to the operator; 
- the performance of the operator for the purpose of any termination clause for non-performance;

- the amount of money which will be spent on capital improvements.

The two main annual budgets (business plans) which are prepared are the operating budgets and the capital improvement budget. Operators will often 'low-ball' the annual budget where there are termination provisions for non-performance, stand asides and guarantees, in order to give them a cushion. Conversely, for the same reasons, owners will often seek to increase the budgeted levels of profit.

The TRI survey indicates that there is a clear trend towards greater owner control in the setting and approval of these budgets and business plans.

\section{Spending}

Notwithstanding the budgetary process referred to above, there is a trend by owners to want to retain the rights to approve expenditure on capital improvements over an agreed dollar amount. This is because owners are taking the view that as management contracts require a minimum percentage of revenue to be put into a reserve account for certain capital improvements, the amounts are such that on large expenditure items they require some approval mechanism to be in place.

Who controls the general manager?

\section{Personnel}

Another area of contention is the appointment of the general manager (and in some of the larger hotels, the financial controller and department managers). It is generally accepted that after the identity of the operator and the terms of the management contract, the general manager is the most important factor in determining the success of the hotel.

Accordingly, owners are most keen to approve the appointment of the general manager and to have a right to request their removal or to veto their removal if desired by the operator. A high number of management contracts have provided for owner approval for the appointment of the general manager, but operators strongly resist any owner say in the removal of the general manager. There are basically two reasons for this:

- First and most importantly, the operator wants to ensure that the general manager reports solely to it, and increasingly includes veto clauses to this end. If the general manager can be removed at the request of the owner, or if the owner can veto his or her removal, then the operator perceives that the general manager may start to react to the owner rather than the operator, who will then lose some of its control.

- Secondly, good-quality general managers are not easy to find 
Greater risk, greater opportunity and operators tend to want to avoid a situation where the owner can force them to find another general manager, with the consequence that the operator also has to find a replacement position for the outgoing general manager.

\section{NON-COMPETE CLAUSES}

In a majority of the surveyed management contracts, there were non-compete provisions preventing the operator from managing or being affiliated with another property within a specified geographical area of the owner's hotel for a specified time.

Operators traditionally resist such clauses, arguing that if another hotel is going to open within the immediate proximity of the hotel, it is better for them to control both hotels. This is a caseby-case decision and a different attitude may apply for central city hotels than may apply to resort destinations.

With the increasing emphasis on market segmentation, where the operator agrees to a non-compete clause, it will often attempt to exclude from the restrictions properties of different types or those oriented towards different markets. Such arguments need to be carefully analysed to determine if a legitimate case can be made. For example, it should be established that different types of properties (full service, all suites, economy or budget, etc) do not draw from some overlapping markets and that the exceptions made on this basis are not detrimental to the volume of business in the subject hotel.

\section{CONCLUSIONS AND STRATEGIES}

In the coming years, owners in the Middle East are expected to continue increasing their control in the operations of their hotels by creating change in traditional contracts. For operators in the region, life is only likely to get harder. They will have to offer written guarantees stating that management fees will be refunded if they do not achieve benchmark profit figures (pre-determined GOP levels).

Contracts will continue to have lower base fees and higher incentive fees. This situation poses both greater risk and greater opportunity for operators. Although the entire payment is not guaranteed, the contract structure arguably aligns the interests of both parties more efficiently. If the hotel is doing well, the operator has an opportunity for greater financial reward than with a strictly base-fee-oriented arrangement.

The reality of the managed hotel sector in the Middle East which encompasses most of its luxury properties - is that operators are working harder to generate more income for their owners. However, they themselves are seeing an ever-dwindling proportion of those profits.

Faced with this dilemma, there are few options left open to them. One is to earn more fees simply by taking on as many contracts as possible, a policy entirely consistent with the regional 


\section{More brands, more options}

\section{Equity shows commitment}

expansion plans of management companies like Six Continents, Le Meridien and Hilton. Moreover, the more properties a chain has, the easier it becomes for it to negotiate contracts and walk away from unpromising ones.

Contracts have also to be viewed and planned with a long-term perspective. This means that significant profit may not be achieved during the first five or even ten years of a contract, but rather in the second and third decades of operation. In developing countries, where hotel management expertise is still at a premium, contract terms can still be as attractive as they used to be in the nowsophisticated Gulf. Within the wider Middle East and surrounding areas such as West Asia, opportunities still exist for business to be done the 'old way'.

Chains with multiple brands can coordinate a more flexible and comprehensive development policy, particularly in destinations with multiple properties under their management. Marriott, for example, is represented in the Middle East with its Ritz-Carlton, JW Marriott, 'core brand' Marriott, Renaissance and Ramada brands, and is shortly to introduce its Marriott Executive Suites and Courtyard brands.

In view of the increased risk associated with incentive-focused contracts, some operators stated that they were investing equity dollars, particularly in the purchase of furniture, fixtures and equipment, or via debt financing, with the expectation of achieving a stronger bargaining position.

These contributions may result in longer terms with higher incentive fees than contracts that do not involve equity. The increasing prevalence of equity contribution may cause difficulties for small operators who have capital restrictions, with the possible result being a reduction in the number of management companies.

Equity contributions are more than simple investments to be measured by bottom-line criteria: they are also mechanisms by which the owner may gauge the operator's commitment to the project. Furthermore, they demonstrate to the banks that the operator stands behind its financial forecasts. Equity injection also shows that the operator is sharing in the burden and benefit of ownership, and is a compelling reason for an owner to want to do business with him.

The only example of a major equity investment in a Gulf hotel is that of the upcoming hotel, The Fairmont Dubai. Canadian chain, Fairmont Hotels and Resorts recently purchased a 49 per cent share in the 394-room property which also offers 115 unfurnished appartments from a member of the Abu Dhabi's royal family. The fact that fairmont is 16.5 per cent owned by Saudi Arabia's famous hotel investor, Prince Alwaeed bin Talal, could explain in part its willingness to offer such a heavy investment in a Dubai hotel where no chain has done so before. But the real answer is that Fairmont is not seeking an immediate advantage. William Fatt, Chairman and CEO of Fairmont, confirmed that the investment was 'the first 
step in a strategic alliance between the private office of His Highness Dr Sheikh Sultan and Fairmont to build and operate a number of hotels in the region and other international markets.'

Loan contributions are perhaps a more acceptable alternative to equity injections, in that they are typically on a shorter term. They are similar to equity contributions in that they increase the operator's risk, and by the same token its incentive in the project. The loan amount is usually specified to cover an identifiable project component such as working capital, inventories, furniture, fixtures and equipment, operating deficits, or a specific combination of these. The loans are funded only after the equity cash and mortgage funding is in place. Terms of the loan usually range from eight to ten years, with the provision that the loan becomes immediately due if the contract is terminated.

It is arguably the French operator Accor in Egypt which has achieved the most comprehensive solution to this problem. In line with a global development policy, Accor SA has formed a 50:50 joint venture with the leading Egyptian El Maghraby Group, called Accor SAE. The company is majority shareholder in six out of the chain's 18 hotels and resorts in Egypt. Although the chain claims that it gains no fee advantage in its joint-venture-owned hotels compared to the purely managed properties, it is at least guaranteed the operation of all the Accor SAE properties. Similar arrangements are in place with local companies in Tunisia, Morocco and Jordan. 